\title{
KARAKTERISASI PLASMA NUTFAH BUAH LOKAL DI KABUPATEN LIMA PULUH KOTA DAN KOTA SOLOK
}

\section{Aries Kusumawati, Nurwanita Ekasari Putri, Nur Oktafiani Azhar, dan Etti Swasti}

\author{
Prodi Agroekoteknologi Fakultas Pertanian Universitas Andalas
}

*E-mail: arieskusumawati@gmail.com

\begin{abstract}
ABSTRAK
Karakterisasi plasma nutfah buah-buahan lokal yang terancam punah di kabupaten Lima Puluh Kota dan kota Solok. Tujuan dari penelitian ini adalah untuk mengeksplorasi dan mengkarakterisasi pohon buah lokal yang ada di kabupaten Lima Puluh Kota dan kota Solok, Sumatera Barat. Hasil dari inventarisasi pengkarakteran tanaman buah lokal ini akan berguna nantinya untuk dijadikan pedoman dan acuan bagi program pemuliaan tanaman buah lokal yang ada di daerah tersebut. Penelitian eksplorasi ini dilaksanakan dari bulan Juli - Desember 2015 di kabupaten Lima Puluh Kota dan kota Solok, Provinsi Sumatera Barat. Pelaksanaan penelitian dilakukan dengan metode survei dengan pengambilan contoh secara sengaja (purposive sampling). Pengukuran terhadap tanaman sampel yang diidentifikasi dan dikarakterisasi dilakukan pada kedua organ vegetatif (daun dan batang) serta generatif (buah dan biji) jika tanaman ditemukan dalam keadaan berbuah. Hasil penelitian ini memberikan informasi bahwa pohon buah lokal menujukkan keragaman fenotipe yang luas pada beberapa karakter. Usaha konservasi telah dilakukan untuk memelihara koleksi biji melalui pembibitan.
\end{abstract}

Kata kunci: Buah lokal, identifikasi, karakterisisi, konservasi

\section{ABSTRACT}

Characterization of local endangered fruits germplasm in Lima Puluh Kota district and Solok city. The purpose of this research is to explore and characterize local fruit trees in the district of Lima Puluh Kota and the city of Solok, province of West Sumatra. The results of the inventory of these local fruit tree plantings will be useful as guides and programs for local fruit crop breeding in the area. This research was conducted from July - December 2015 in Lima Puluh Kota district and Solok city, Province of West Sumatera. Implementation of the research was conducted by survey method by using the purposive sampling. Measurements on plant samples were identified and characterized on vegetative organs (leaves \& stems) and generative (fruit \& seeds) if the plants were found in a fruitful state. The results of this study provide information that local fruit trees exhibit a wide variety of phenotypes in some characters. Efforts have been made to make seed collections through nurseries.

Keywords: characterization, conservation, identification, local fruit, 


\section{PENDAHULUAN}

Sumber daya genetik (plasma nutfah) tanaman adalah dasar biologis dari ketahanan pangan dan, secara langsung atau tidak langsung, mendukung mata pencaharian setiap orang di Bumi. Sumber daya genetik tanaman berguna untuk pangan dan pertanian yang terdiri dari keanekaragaman benih dan bahan tanam varietas tradisional dan kultivar modern, tanaman kerabat liar dan spesies tumbuhan liar lainnya. Sumber daya ini digunakan sebagai pangan, pakan untuk hewan domestik, serat, pakaian, tempat tinggal dan energi. Konservasi dan penggunaan berkelanjutan diperlukan untuk memastikan produksi tanaman dan memenuhi pertumbuhan tantangan lingkungan dan perubahan iklim. Erosi sumber daya ini menjadi parah ancaman terhadap keamanan pangan dunia dalam jangka panjang. (FAO, 2015)

Buah-buahan tropis sebagai bahan pangan pada masa lalu sebagian besar diabaikan namun pada saat ini telah mendapatkan prioritas tinggi di kalangan tanaman hortikultura untuk pengembangan pertanian dan selama dekade terakhir. Asia mencatat peningkatan $66 \%$ dalam produksi buah, tertinggi di dunia. Wilayah dari Selatan, Tenggara dan Asia Timur penting dalam hal ini dan empat negara, yaitu, India, Indonesia, Thailand, dan Cina mencapai $50 \%$ dari produksi total buah global. Dinegara wilayah ropis ini, buah-buahan prouduksi buah $30 \%$ - 59\% dari total lahan pertanian pendapatan terutama untuk petani kecil dan petani marjinal. dengan demikian berkontribusi terhadap perekonomian masyarakat pedesaan sebagian besar masyarakat pertanian. Sudah terbukti bahwa buah-buahan tropis berkontribusi secara signifikan terhadap peningkatan gizi dan kesehatan manusia. Ini adalah sumber yang kaya vitamin dan mineral dan memiliki energi makanan yang tinggi. Dengan demikian, mengingat kegunaannya yang beragam, buah-buahan tropis berkontribusi jauh untuk keamanan pangan dan gizi, penghasilan pendapatan, pengurangan kemiskinan dan ekosistem dan kelestarian lingkungan. Perkembangan pertanian yang cepat dan industrialisasi, mengubah pola penggunaan lahan, deforestasi skala besar.

Walaupun Indonesia mempunyai potensi yang sangat besar untuk menghasilkan beraneka jenis buahbuahan, sampai saat ini Indonesia masih merupakan net importer buah-buahan. Masalah kualitas, rasa, tampilan, standarisasi, kontinyuitas ketersediaan dan daya tahan simpan menjadi kendala utama kemampuan buah-buahan lokal Indonesia untuk bisa bersaing dengan buah-buahan impor. Di samping itu, mengkonsumsi buah-buahan impor merupakan prestise tersendiri bagi kalangan masyarakat umum. Oleh karena itu, di samping menggalakkan edukasi akan pentingnya mengkonsumsi buah, juga perlu dilakukan kampanye kecintaan terhadap buah-buahan lokal yang dibarengi dengan upaya pengembangan buah-buahan lokal secara holistik, yang mencakup keseluruhan kegiatan perencanaan, arahan kawasan, usaha dan produk, informasi, penelitian dan pengembangan, pemberdayaan, pembiayaan, pengawasan dan peran serta masyarakat (Ariningsih, 2018)

Menurut Direktur Budidaya dan Pascapanen Buah Ditjen Hortikultura Kementrian Pertanian data PDB menyebutkan produksi buah nasional naik selama 2005 - 2010 sebesar $63.5 \%$ begitu juga produksi buah naik di kurun lima tahun terakhir hingga $29.21 \%$. Namun, minat dan ketersediaannya di pasar modern menjadikannya kalah bersaing bahwa buah lokal dengan buah import lainnya. Wakil Menteri Pertanian, Bayu Krisnamurthi mengatakan tidak otomatis menunjukkan bahwa buah lokal telah terpuruk di negeri sendiri. Secara jumlah (impor buah-buahan) sebenarnya masih sangat kecil dibandingkan produksi 
nasional, yakni hanya 3.5\% pada 2010. Pada tahun lalu, produksi buah nasional 19,03 juta ton sedangkan impor hanya 667 ribu ton sementara ekspor buah Indonesia 276 ribu ton (Anonim, 2015a). Jika dibandingkan antara buah ekspor dengan buah impor masih defisit. Jika dihitung, buah yang kita impor hanya sekitar $7 \%-8 \%$ dari produksi buah nasional. Pasar buah local masih membanjiri pasar kita,namun hanya pasar modern saja yang dibanjiri oleh buah impor. Kendati demikian, pihaknya menilai pemerintah harus melakukan pembenahan, terutama dalam hal manajemen pasokan buah karena tahun 2015 Indonesia sudah harus menghadapi perdagangan bebas, yang tentunya akan berpengaruh pada kebijakan dan kehidupan di masyarakat (Anonim, 2015b).

Adanya pergeseran buah lokal oleh buah impor tersebut menyebabkan terancamnya keberadaan sumberdaya genetik (plasma nutfah) buah-buahan lokal, sehingga yang terjadi sekarang, adalah semakin langkanya jenis-jenis buah-buahan lokal dan pada suatu saat akan menuju kepunahan. Sumatera Barat termasuk wilayah yang kaya akan keanekaragaman jenis buah-buah lokal yang pada sekitar 30 tahun yang lalu nasih bernilai ekonomi dan diperdagangkan di pasar-pasar terutama tradisional.

Sebagai antisipasi dari permasalahan tersebut, perlu dilakukan penyelamatan terhadap sumber daya genetik local (plasma nutfah) tersebut. Swasti (2007) plasma nutfah dapat dikatakan sebagai bahan mentah untuk perbaikan tanaman (varietas baru) dan merupakan sumber daya genetik yang tidak tergantikan. Menurut Fauza (2005) pengelolaan sumber daya genetik tumbuhan meliputi upaya untuk melestarikan, mengamankan sekaligus memamfaatkan keanekaragaman genetika seoptimal mungkin sehingga berguna bagi generasi sekarang maupun yang akan datang.
Kegiatan eksplorasi merupakan tahap awal untuk mengetahui keberadaan dari plasma nutfah buah lokal. Eksplorasi adalah kegiatan mencari, mengumpulkan, serta meneliti jenis varietas lokal tertentu (di daerah tertentu) untuk mengamankan dari kepunahannya. Langkah ini diperlukan guna menyelamatkan varietas-varietas lokal dan kerabat liar yang semakin terdesak keberadaannya. Kegiatan identifikasi dilakukan bersamaan dengan kegiatan eksplorasi. Soedomo (2000) menyatakan bahwa identifikasi sifatsifat kualitatif dan kuantitatif dari suatu plasma nutfah dapat dilakukan melalui karakterisasi.Berdasarkan hal di atas, maka kegiatan penelitian "Identifikasi Keberadaan Plasma Nutfah BuahBuahan Lokal Sumbar yang Terancam Punah Dalam Rangka Mengantisipasi Buah-Buah Import" dilakukan dengan tujuan menghimpun dan mendapatkan informasi tentang keberadaaan berbagai jenis buah-buahan lokal Sumatera Barat dan melakukan karakterisasi dan koleksi terhadap benih-benih atau bibit sebagai upaya konservasi.

Eksplorasi, koleksi, dan konservasi tanaman buah tropika perlu terus dilakukan karena ancaman terhadap kepunahan (extinction) sumber daya genetik semakin menuju ambang berbahaya. Hal ini terjadi akibat perubahan orientasi sistem pertanian, perluasan distribusi dan peningkatan intensitas serangan hama dan penyakit, deforestasi dan perubahan iklim yang semakin ekstrim (Hermanto et al. 2013).

\section{METODE}

Kegiatan eksplorasi ini dilaksakanan Juli - Desember 2015. Wilayah yang menjadi target penelitian adalah kabupaten Lima Puluh Kota dan kota Solok.

Bahan yang digunakan adalah seluruh bagian organ tanaman di masing-masing lokasi baik pada fase vegetatif maupun generatif. Bahan lain 
yang menunjang penelitian ini adalah polybag, pupuk NPK, Urea, KCL, SP36, tanah, pukan dan pestisida sebagai sarana konservasi terhadap buah dan biji yang ditemukan pada saat kegiatan dilakukan. Alat yang digunakan adalah GPS, alat ukur, camera, gunting tarik, color chart, dan gunting,

Metode penelitian dilakukan dalam bentuk survey. Pengambilan sampel pohon buah dilakukan secara sengaja (Purposive Sampling). Jumlah sampel tidak dibatasi dengan pertimbangan harus mewakili populasi. Sebelum kegiatan eksplorasi dimulai terlebih dahulu dilaksanakan survei pendahuluan dilakukan untuk mendapatkan informasi dan memastikan titik sebar plasma nutfah yang akan dikarakterisasi. Kemudian dilakukan identifikasi melalui pengukuran terhadap karakter seluruh bagian tanaman. Biji-biji dari plasma nutfah dikoleksi minimal 10 biji atau bagian tanaman yang dapat dijadikan sebagai bahan konservasi. Perbanyakan akan sangat bergantung pada musim berbuah dari plasma nutfah yang dimaksud.

Upaya perbanyakan dilakukan dengan menanam biji-biji yang ditemukan dilapangan baik berupa benih maupun perbanyakan secara vegetatif pada polybag yang berukuran $20 \mathrm{~cm} \mathrm{x}$ $15 \mathrm{~cm}$. Setiap jenis buah ditanam 10 benih atau stek di dalam polybag yang sudah berisi media tanah yang dicampur pukan dengan perbandinga 1:1. Benih tersebut ditempatkan dan dipelihara dengan memberikan naungan berupa paranet sampai bibit cukup besar untuk dipindahkan ke lapangan. Pemberian pupuk NPK pada bibit dilakukan dengan menggunakan dosis $2-5 \mathrm{~g}$ per polybag. Setiap satu polybag ditanam satu bibit tanaman. Pengamatan dilakukan pada semua organ tanaman baik pada fase vegetatif maupun generatif dan disesuaikan dengan kondisi fase tanaman yang ditemukan di lapangan.
Pengamatan morfologi dilakukan pada batang, daun, bunga dan buah (jika ada) mengikuti cara yang ditulis oleh Tjitrosoepomo (2007). Penentuan cabang dan daun yang diamati dilakukan dengan metoda mengacu kepada Denian et al. (1994). Masing-masing aksesi pohon yang diamati dibagi atas empat sektor yaitu utara, selatan, barat, dan timur. Pengamatan tiap sektor dilakukan terhadap empat cabang secara acak. Tiap cabang diamati sampel daun yang terletak pada daun keenam dari pucuk, dimana pada setiap sektor terdapat empat helai daun. Pengamatan bunga dan buah dilakukan secara tentatif hanya pada tanaman yang terdapat bunga dan buah pada saat karakterisasi. Nilai suatu karakter ditentukan dengan menghitung rata-rata dari semua sampel dalam satu aksesi.

Hasil pengamatan akan disajikan dalam bentuk deskriptif pada data kualitatif dan dianalisis secara statistic pada data kuantitatif seperti nilai ratarata, ragam (Steel and Torrie, 1995) dan pengelompokan variabilitas fenotipik mengacu pada Pinnaria (1995),yaitu: bila $\sigma_{f}^{2} \geq 2 \quad \mathrm{Sd}_{\sigma_{f}^{2}}=$ variabilitas fenotipik luas dan bila $\sigma_{f}^{2}<2 \mathrm{Sd}_{\sigma_{f}^{2}}=$ variabilitas fenotipik sempit.

\section{HASIL DAN PEMBAHASAN}

Kegiatan eksplorasi adalah kegiatan mengumpulkan, mengkoleksi seluruh bagian tanaman atau bagian perbanyakan vegetatif lainnya dengan tujuan untuk meningkatkan keragaman populasi. Identifikasi adalah kegiatan mengkarakterisasi seluruh organ tubh tanaman (akar, batang, daun, bunga dan buah serta biji). Kedua kegiatan ini selalu beriringan dilakukan guna menghimpun informasi baik berupa keunggulan atau kelemahan tanaman yang nantinya berguna dalam upaya perbaikan genetik tanaman dalam program pemuliaan tanaman. Kegiatan ini adalah bahan baku yang diperlukan 
sehingga memudahkan dalam menyusun strategi pemuliaan tanaman tertentu. Dalam penelitian ini telah dilakukan eksplorasi dan identifikasi buah-buah lokal yang disajikan dalam Tabel 1.

Tabel 1. Daerah Eskplorasi

\begin{tabular}{ll}
\hline \multicolumn{1}{c}{ Daerah } & $\begin{array}{l}\text { Buah lokal yang } \\
\text { ditemukan }\end{array}$ \\
\hline Kota Solok & $\begin{array}{l}\text { Ceremai dan } \\
\text { Kesemek }\end{array}$ \\
\hline Kabupaten Lima & $\begin{array}{l}\text { Rambai, Tapuih, } \\
\text { Puluh Kota }\end{array}$ \\
Sijontiak, Rambai \\
\hline
\end{tabular}

\section{Kabupaten Lima Puluh Kota}

Secara geografis, kabupaten Lima Puluh Kota terletak antara $0^{\circ} 25^{\prime}, 28,71$ " LU dan $0^{\circ} 22^{\prime} 14,52^{\prime \prime}$ LS dan $100^{\circ} 15^{\prime}$ $44,10 "$ - $100{ }^{\circ} 50$ ' 47,80" BT. Luas daratan mencapai $3.354,30 \mathrm{~km}^{2}$ yang berarti $7,94 \%$ dari daratan Provinsi Sumatera Barat yang luasnya 42.229,64 $\mathrm{km}^{2}$. Kabupaten Lima Puluh Kota diapit oleh empat kabupaten dan satu provinsi, yaitu Kabupaten Agam, Kabupaten Tanah Datar, Kabupaten Sijunjung, dan Kabupaten Pasaman serta Provinsi Riau. Kabupaten Lima Puluh Kota terdiri dari tiga belas kecamatan, yang terluas adalah kecamatan Kapur IX sebesar $723,36 \mathrm{~km}^{2}$ dan yang terkecil adalah kecamatan Luak yaitu $61,68 \mathrm{~km}^{2}$. Di daerah ini terdapat 3 buah gunung berapi yang tidak aktif yaitu gunung Sago $(2.261 \mathrm{~m})$, gunung Bungsu $(1.253 \mathrm{~m})$, gunung Sanggul (1.495 m) serta 17 buah sungai besar dan kecil yang mengalir dan telah banyak dimanfaatkan oleh masyarakat untuk pengairan (irigasi). (Pemprovsumbar, 2018).

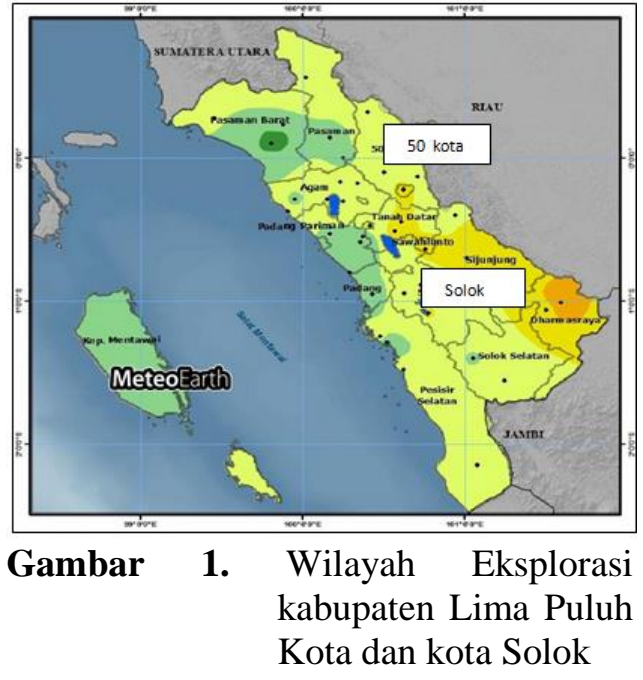

Di daerah Kabupaten Lima Puluh Kota ditemukan tanaman rukan-rukan, rambai, sijontiak, kapulasan dan tapuih. Buah-buah ini menurut masyarakat setempatbanyak dijumpai di pasar-pasar tradisional. Namun sekarang jarang yang memperjual belikannya sehingga tanaman ini cenderung tidak dipelihara, bahkan ditebang oleh pemiliknya karena tidak memiliki nilai ekonomis yang tinggi.

\section{1) Rambai}

Rambai merupakan tanaman tahunan yang biasa ditemui di pekarangan rumah dan hutan. Namun keberadaannya sudah mulai jarang ditemukan di pekarangan rumah sehingga populasi yang tertinggal hanya di pinggiran dan dalam hutan. Bunga rambai merupakan bunga majemuk, dimana setiap bunga tunggalnya berwarna kuning. Ukuran buah bisa mencapai $5 \mathrm{~cm}$ dan berisi $1-$ 3 biji dalamsetiap buahnya. Buah muda berwarna hijau dan setelah matang akan berwarna kuning kecoklatan atau krem (Gambar 2).

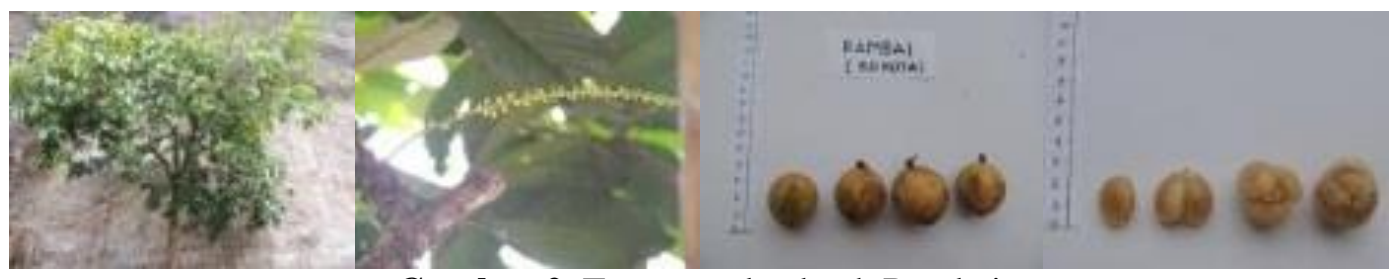

Gambar 2. Tanaman dan buah Rambai 


\section{2) Sijontiak}

Buah sijontiak dikenal sebagai buah khas kabupaten Lima Puluh Kota yang mudah merekah ketika buah matangnya disentuh. Buah sijontiak merupakan buah rangkai yang berisi $10-20$ buah per rangkainya. Kulit buah keras dan berwarna krem. Buah yang keras ini mudah dibuka ketika matang. Cukup dengan memberi sedikit sentilan pada buah maka akan keluarlah daging buah berwarna jingga. Rasanya manis dan segar, setiap buah memiliki $2-3$ rongga. Biji berwarna kuning dan pipih (Gambar 3.)

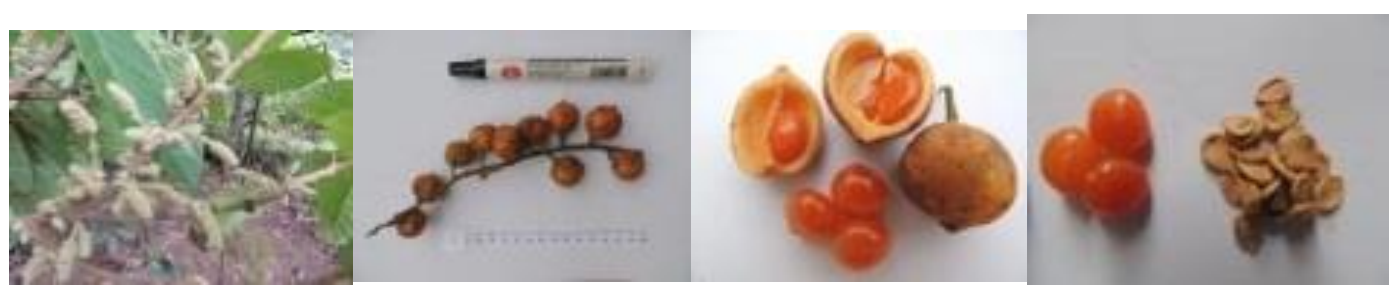

Gambar 3. Tanaman dan buah Sijontiak

\section{3) Rukam}

Buah rukam dikenal sebagai buahbuahan hutan tetapi diperjualbelikan di pasar tradisional. Walaupun hidupnya di dalam hutan, namun populasinya terus berkurang karena tidak ada usaha untuk penanaman kembali bahkan pemilik tanah membabatnya dan menggantikan dengan tanaman komersial lainnya. Gambar 4 menunjukkan bahwa buah rukam memiliki tangkai buah yang sangat panjang dan ukuran buahnya juga cukup besar. Kulit buah tebal dan berwarna coklat. Buah rukam memiliki $2-3$ buah rongga yang setiap rongga berisi satu daging buah berwarna jingga.
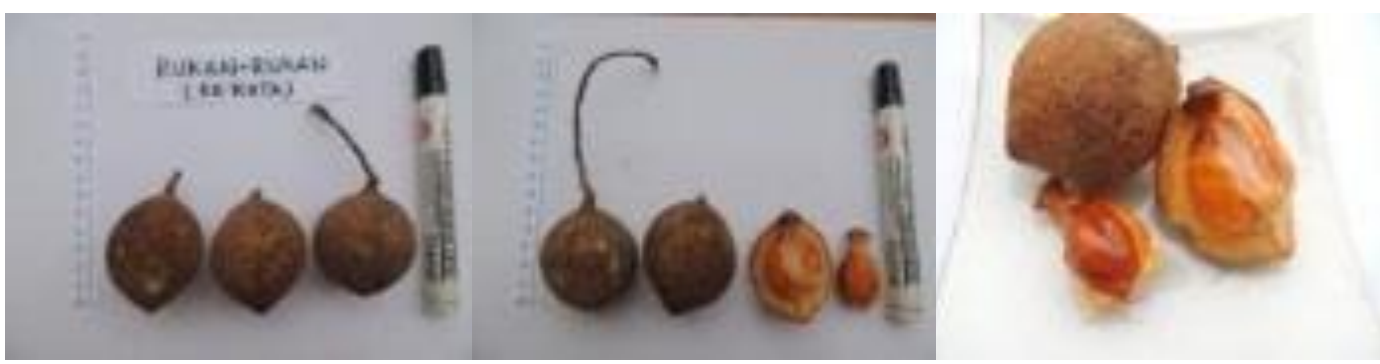

Gambar 4. Buah Rukam

\section{Kota Solok}

Kota Solok terletak secara geografis terletak pada posisi $0^{\circ} 32^{\prime \prime} \mathrm{LU}-1^{\circ} 45^{\prime \prime}$ LS dan $100^{\circ} 27^{\prime \prime}$ BT - $101^{\circ} 41^{\prime \prime}$ BT dengan luas $57,64 \mathrm{~km}^{2}(0,14 \%$ dari luas Provinsi Sumatera Barat). Wilayah administrasi Kota Solok berbatasan dengan Kabupaten Solok dan Kota Padang. Kota Solok memiliki peran sentral di dalam menunjang perekonomian masyarakat Kota Solok dan Kabupaten Solok pada umumnya. Topografi kota Solok bervariasi antara dataran dan berbukit dengan ketinggian
$390 \mathrm{~m}$ dpl serta curah hujan rata-rata $184,31 \mathrm{~mm}^{3}$ per tahun. Terdapat tiga anak sungai yang melintasi Kota Solok, yaitu sungai Batang Lembang, sungai Batang Gawan dan sungai Batang Air Binguang. Suhu udara berkisar dari $26,1{ }^{\circ} \mathrm{C}$ sampai $28,9{ }^{\circ} \mathrm{C}$. Dilihat dari jenis tanah, 21,76\% tanah di Kota Solok merupakan tanah sawah dan sisanya $78,24 \%$ berupa tanah kering. Batas wilayah utara adalah kecamatan Nagari Tanjuang Bingkuang, Aripan dan Kuncir kabupaten Solok. Di selatan adalah kecamatan Nagari Gaung, Panyakalan, Koto Baru, Selayo kabupaten Solok, 
Nagari Muaro Paneh dan kota Padang. Sedangkan di barat adalah kecamatan Nagari Selayo, Koto Sani kabupaten Solok (Anonim, 2018).

Buah lokal yang bisa ditemukan pada kota Solok ini adalah buah kesemek yang cenderung hidup di dataran tinggi dan kali ini ditemukan hanya beberapa titik disekitar Nagari Alahan Panjang. Populasinya pun semakin berkurang karena tidak dibudiyakan kembali oleh pemiliknya bahkan ditebang karena tidak terlalu menguntungkan Selain itu, juga ditemukan buah ceremai yang populasinya juga semakin berkurang.

\section{1) Kesemek}

Kesemek memiliki nama latin Diospyros kaki L.f dan ada juga yang menyebutnya dengan nama persimmon atau buah kaki. (Suhardi et al. 2006; Ishaq et al. 2012; Kurniasari, 2017). Kesemek merupakan tanaman berbentuk pohon dengan tinggi tanaman berkisar antara 5-15 $\mathrm{m}$. Daunnya bulat telur dengan bunga berwarna putih kekuningan. Buah berbentuk bulat dengan pinggir seperti berbatas, bagian pangkal buah datar dan tampak kelopak buah yang jelas pada ujungnya. Warna buah muda hijau kekuningan dan setelah matang menjadi merah jingga hingga merah cerah. Daging buah tebal dan rasanya manis bila masak optimal. Rasa kelat dapat dihilangkan dengan mencelupkan buah ke dalam air kapur. Buah yang telah tua di pohon tidak dapat segera dimakan. Petani atau pedagang biasanya merendam buah kesemek dalam air kapur 3\% - 5\%, lebih dari 48 jam untuk menghilangkan rasa asam dan kelat (Suhardi, 2006).

Kesemek merupakan tanaman yang sering ditemukan di daerah berhawa sejuk (dingin) sehingga sering ditemukan di daerah dataran tinggi, Tanaman tahunan ini berbunga sekali setahun. Buah yang berbentuk bulat ini berwarna hijau dan akan berubah menjadi kuning ketika sudah matang (Gambar 5).

Tabel 2. Karakter kualitatif tanaman kesemek

\begin{tabular}{ll}
\hline Karakter & Kesemek \\
\hline Permukaan batang & Kasar \\
\hline Warna kulit batang & Abu-abu \\
\hline Tipe percabangan & Intermediate \\
\hline Bentuk kanopi & Irregular \\
\hline Bentuk ujung daun & $\begin{array}{l}\text { Acute, } \\
\text { acuminate }\end{array}$ \\
\hline Tepi daun & $\begin{array}{l}\text { Rata, } \\
\text { bergelombang }\end{array}$ \\
\hline Bentuk daun & Ovate, elliptic \\
\hline $\begin{array}{l}\text { Warna daun } \\
\text { permukaan atas }\end{array}$ & Hijau tua \\
\hline $\begin{array}{l}\text { Warna daun } \\
\text { permukaan bawah }\end{array}$ & Hijau tua \\
\hline $\begin{array}{l}\text { Permukaan daun } \\
\text { atas }\end{array}$ & Halus \\
\hline $\begin{array}{l}\text { Permukaan daun } \\
\text { bawah }\end{array}$ & Kasar \\
\hline Tulang daun & Menyirip \\
\hline $\begin{array}{l}\text { Bentuk pangkal } \\
\text { daun }\end{array}$ & Obtuse, round \\
\hline Bentuk buah & Oblate, ovoid \\
\hline $\begin{array}{l}\text { Warna kulit buah } \\
\text { matang }\end{array}$ & Jingga \\
\hline $\begin{array}{l}\text { Warna daging } \\
\text { buah matang }\end{array}$ & Jingga \\
\hline $\begin{array}{l}\text { Kematangan buah } \\
\text { Bentuk pangkal } \\
\text { buah }\end{array}$ & \begin{tabular}{l} 
Tidak merata, \\
merata \\
\hline Bentuk ujung buah \\
Truncate
\end{tabular} \\
\hline mammifoam \\
\hline Warna biji & Obovoid \\
\hline & Kuning \\
\hline ani
\end{tabular}

Hasil pengamatan pada Tabel 2 menunjukan bahwa terdapat keragaman fenotipik pada karakter kualitatif tanaman kesemek yang diamati. Variasi terjadi pada bentuk ujung daun, bentuk pangkal daun, tepi daun, bentuk daun, bentuk buah, kematangan buah dan bentuk pangkal buah. Hal ini merupakan peluang untuk melakukan seleksi dalam program pemuliaan tanaman untuk merakit buah kesemek dengan karakter yang unggul. 


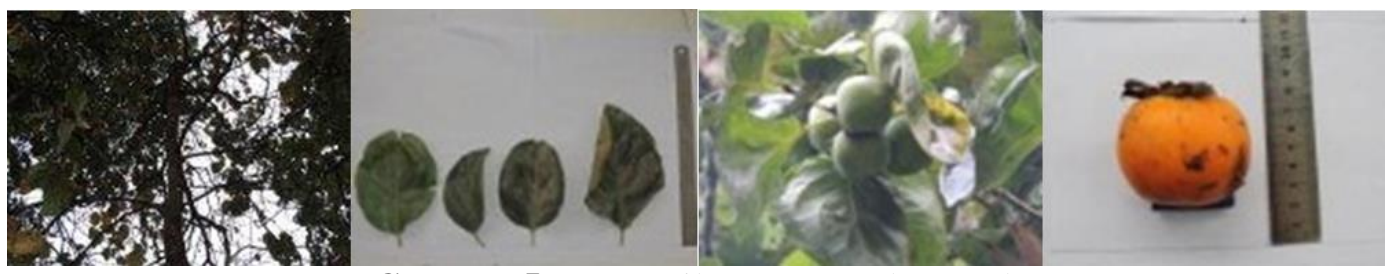

Gambar 5. Penampilan tanaman kesemek

Tanaman kesemek dapat diperbanyak dengan mengggunakan tunas akar, bibit hasil sambung, atau kultur jaringan. Perbanyakan menggunakan akar mampu menghasilkan mata tunas yang banyak yang mampu tumbuh menjadi tanaman dewasa. Kelemahannya adalah usia berbuah lama, sekita $7-10$ tahun. Dianajurkan perbanyakannya melalui teknik sambung dengan batang bawah dari tunas anakan dan batang atas diambil dari pohon dewasa yang dianggap unggul atau menggunakan pohon induk yang ditentukan sebelumnya. (Sunarjono, 1999 dalam Suhardi, 2006).

\section{2) Ceremai}

Ceremai (Phyllanthus acidus (L.) Skeells) merupakan tanaman tahunan yang memiliki buah bersegi dan berwarna kuning muda. Bunganya yang berangkai atau tersusun secara majemuk menyebabkan buahnya pun dalam kondisi yang majemuk. Rasa buah yang asam membuat buah ini sering dijadikan asinan buah.

Tabel 3 menunjukan bahwa terdapat variasi pada bentuk ujung daun, warna pemukaan atas daun, bentuk pangkal daun, bentuk pangkal buah, bentuk ujung buah dan bentuk biji. Karakter kualitatif ini merupakan karakter yang sedikit dipengaruhi oleh lingkungan sehingga lebih cenderung ditentukan oleh faktor genetiknya.
Tabel 3. Karakter kualitatif tanaman ceremai

\begin{tabular}{ll}
\hline Karakter & Sifat \\
\hline Permukaan batang & Kasar \\
\hline Warna kulitbatang & Abu-abu \\
\hline Tipe percabangan & Intermediate \\
\hline Bentuk kanopi & Irregular \\
\hline Bentuk ujung daun & $\begin{array}{l}\text { Accuminatte, } \\
\text { acute, }\end{array}$ \\
\hline Tepi daun & Rata \\
\hline Bentuk daun & Eliptic, ovate \\
\hline $\begin{array}{l}\text { Warna permukaan } \\
\text { atas daun }\end{array}$ & $\begin{array}{l}\text { Hijau, hijau } \\
\text { kemerahan }\end{array}$ \\
\hline $\begin{array}{l}\text { Warna permukaan } \\
\text { bawah daun }\end{array}$ & Hijau muda \\
\hline Permukaan atas daun & Licin \\
\hline $\begin{array}{l}\text { Permukaan bawah } \\
\text { daun }\end{array}$ & Licin \\
\hline Tulang daun & Menyirip \\
\hline Bentuk pangkal daun & Round, obtuse \\
\hline $\begin{array}{l}\text { Warna mahkota } \\
\text { bunga }\end{array}$ & Merah muda \\
\hline Warna stigma & Kuning \\
\hline Bentuk buah & Oblate \\
\hline $\begin{array}{l}\text { Warna kulit buah } \\
\text { matang }\end{array}$ & Kuning \\
\hline $\begin{array}{l}\text { Warna daging buah } \\
\text { matang }\end{array}$ & $\begin{array}{l}\text { Kuning } \\
\text { keputihan }\end{array}$ \\
\hline Kematangan buah & Merata \\
\hline Bentuk pangkal buah & $\begin{array}{l}\text { Depressed, } \\
\text { Truncate }\end{array}$ \\
\hline Bentuk ujung buah & $\begin{array}{l}\text { Depressed, } \\
\text { mammifoam }\end{array}$ \\
\hline Bentuk biji & $\begin{array}{l}\text { Spheroid, } \\
\text { ellipsoid }\end{array}$ \\
\hline Warna kulit biji & Coklat \\
\hline & \\
\hline Mana
\end{tabular}


Tabel 4. Karakter kuantitatif pada kesemek dan ceremai

\begin{tabular}{lrrrrrrr}
\hline Aksesi & $\begin{array}{c}\text { Panjang } \\
\text { daun }\end{array}$ & \multicolumn{1}{c}{$\begin{array}{c}\text { Lebar } \\
\text { daun }\end{array}$} & $\begin{array}{c}\text { Panjang } \\
\text { tangkai } \\
\text { daun }\end{array}$ & $\begin{array}{c}\text { Diameter } \\
\text { buah }\end{array}$ & $\begin{array}{c}\text { Panjang } \\
\text { biji }\end{array}$ & $\begin{array}{c}\text { Lebar } \\
\text { biji }\end{array}$ & $\begin{array}{c}\text { Jumlah } \\
\text { biji per } \\
\text { buah }\end{array}$ \\
\hline A. Kesemek & & & & & & & \\
\hline Range & $15.11-$ & $9.40-$ & $1.85-$ & $4.50-$ & $0.30-$ & 0.30 & \\
& 19.03 & 13.80 & 2.25 & 6.00 & 0.40 & & \\
\hline Rataan & 17.20 & 11.57 & 2.08 & 5.00 & 0.34 & 0.20 & 7.40 \\
\hline Ragam & 1.93 & 1.34 & 0.02 & 0.34 & 0.00 & 0.00 & 1.30 \\
\hline Stdev & 1.39 & 1.16 & 0.14 & 0.58 & 0.04 & 0.00 & 1.14 \\
\hline Kriteria & sempit & Sempit & sempit & sempit & sempit & sempit & sempit \\
\hline B. Ceremai & & & & & & & \\
\hline Range & $5.00-$ & $2.78-$ & $0.28-$ & $1.3-2.3$ & $0.5-0.9$ & $0.3-0.9$ & 1.00 \\
& 7.40 & 4.08 & 0.40 & & & & \\
\hline Rataan & 6.63 & 3.18 & 0.33 & 1.79 & 0.69 & 0.59 & 1.00 \\
\hline Ragam & 0.76 & 0.27 & 0.00 & 0.13 & 0.02 & 0.04 & 0.00 \\
\hline Stdev & 0.87 & 0.52 & 0.05 & 0.36 & 0.15 & 0.20 & 0.00 \\
\hline Kriteria & Sempit & Sempit & Sempit & Sempit & Sempit & Sempit & Sempit \\
\hline
\end{tabular}

Tabel 4 menunjukkan keragaman fenotipe yang sempit dari karakter yang diamati sehinga bisa dikatakan bahwa tanaman ini homogeny atau memiliki kekerabatan yang dekat. Oleh karena itu perlu meningkatkan keragaman populasi agar bisa mendukung kegiatan pemulian dengan menambah wilayah eskplorasi dan meningkatkan jumlah sample aksesi yang diamati.

\section{Konservasi}

Upaya penyelamatan plasma nutfah bisa dilakukan secara in-situ dan ex-situ. Pre-nursery dilakukan di Siteba dan main-nursery dilakukan di rumah setengah bayang Fakultas Pertanian Unand. Setelah bibit dewasa akan ditanam di kebun koleksi Kebun Percobaan Fakultas Pertanian Universitas Andalas (Gambar 6).

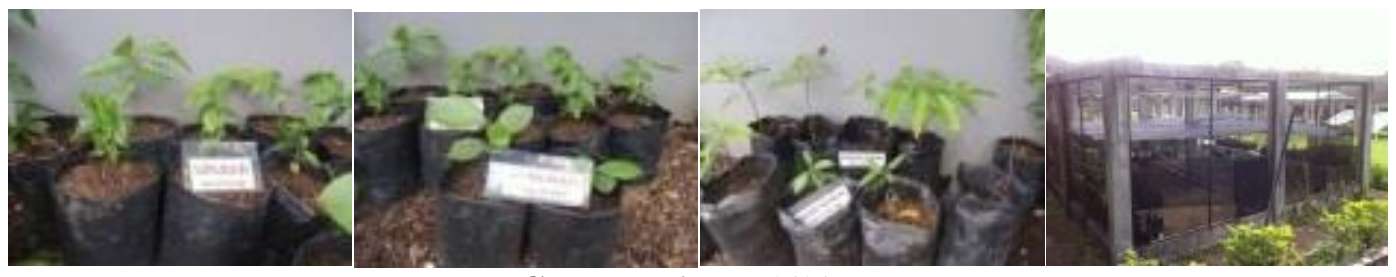

Gambar 6. Pembibitan

\section{SIMPULAN DAN SARAN}

\section{Simpulan}

Populasi buah-buah lokal yang diamati semakin berkurang akibat kurangnya kesadaran masyarakat akan pentingnya plasma nutfah lokal. Buah lokal yang ditemukan di kota Solok adalah kesemek dan ceremai, sedangkan di kabupaten Lima Puluh Kota adalah rambai, sijontiak, tapuih, dan kapulasan. Beberapa buah lokal menunjukan keragaman fenotipik yang perlu segera diselamatkan sebagai sumber gen dalam program pemuliaan tanaman. Telah diperoleh beberapa bibit hasil persemaian dari biji pada buah-buah lokal yang sudah berbuah ketika penelitian ini dilaksanakan.

\section{Saran}

Perlu dilakukan perluasan areal eksplorasi untuk buah lokal yang sama serta kerjasama dengan pemerintah 
daerah setempat agar upaya penyelamatan buah-buah lokal ini lebih komprehensif dan terintegrasi dalam program pemerintah sehingga wilayah cakupan lebih luas dan terkoordinir. Masih banyak buah lokal yang belum tersentuh dalam upaya konservasi dimana populasinya masih ada dalam hutan.

\section{UCAPAN TERIMA KASIH}

Penelitian ini terlaksana atas bantuan pendanaan penelitian DIPA Unand tahun 2015 pada skim Penelitian Dosen Muda. Terima kasih dan penghargaan yang tulus disampaikan kepada Alm. Dr. Hamda Fauza yang memprakasai penelitian ini.

\section{DAFTAR PUSTAKA}

Anonim. 2018. Data Penduduk. http://www.limapuluhkotakab.go.id/h al-data-penduduk.html. [18 Juni 2018]

Anonim. 2012. Kasiat dan Manfaat Matoa.

http://www.bestbudidayatanaman.co $\mathrm{m} / 2012 / 11 /$ khasiat-dan-manfaatbuah-matoa.html. $\quad[12$ Desember 2015]

Anonim. 2013. Wild edible tree-kasai. http://rimbagunong.blogspot.co.id/20 13/01/wild-edible-tree-7-kasai.html [5 Desember 2015]

Anonim. 2015a. Buah Duwet (Syzigium cumini).

http://ar10.xtgem.com/tip/trick4 [2 Desember 2015]

Anonim. $2015 b$. http://www.republika.co.id/berita/sen ggang/unik/12/11/06/md103h-limabuah-langka-indonesia-rasa-surga-2 [10 Desember 2015]

Anonim. 2015 c. http://rimbagunong.blogspot.co.id/20 13/01/wild-edible-tree-7-kasai.html [5 Desember 2015]

Anonim. 2018. Letak geografis. http://www.solokkota.go.id/index.ph $\mathrm{p} /$ profil/potensi/letak-geografis $\quad[18$ Juni 2018].
Ariningsih, E. 2018. Konsumsi, Produksi dan Strategi Pengembangan Buah-buahan Lokal Indonesia. https://pse.litbang.pertanian.go.id/ind /pdffiles/PROS2013_05B_Ening.pdf [18 Juni 2018]

Chahal, G.S and Gosal SS. 2003. Principles and Procedurs of Plant Breeding: Biotechnological and Conventional Approaches. Narosa, New Delhi. [En.]

Denian, A dan A. Fiani. 1994. Karakteristik Morfologis Beberapa Nomor Tanaman Gambir. Prosiding Seminar Penelitian Tanaman Rempah dan Obat. Sub-Balitro Solok, (4): 29 -30 .

Fauza, H. 2005. Gambir (Uncaria gambir (Hunter)Roxb.). Dalam: Baihaki, A., Hasanuddin, Elfis, P. Hidayat, A. Sugianto, dan Z. syarif (Eds.) Kondisi Beberapa Plasma Nutfah Komoditi Pertanian Penting Dewasa ini. PPS Unpad - KNPN Litbang Deptan. Hal : $168-182$.

Hermanto C., Indriani N.L.P., dan Hadiati S. 2013. Keragaman dan Kekayaan Buah Tropika Nusantara. Badan Penelitian dan Pengembangan Pertanian Kementerian Pertanian. Hal: $\quad 170$. http://hortikultura.litbang.pertanian.g o.id/downloads/B_tropika.pdf. [18 Juni 2018].

Ishaq, I. dan Mochamad, 2012. Buah Kesemek: Potensi Sumberdaya Genetik Kabupaten Garut Jawa Barat. Lokakarya Nasional Pengelolaan dan Perlindungan Sumber Daya Genetik di Indonesia: Manfaat Ekonomi untuk Mewujudkan Ketahanan Nasionla. Balai Pengkajian Teknologi Pertanian Jawa Barat, Bandung.

Kurniasari, I. 2017. Prediksi Kandungan Kimia Buah Kesemek (Diospyros kaki L.) dengan Spektroskopi Nir.[Tesis]. Pascasarjana IPB.

Mahmoud, I., M. Marzouk, M. Moharram, El-Gindi, dan A. Hasan. 2001. Acylated Flavonol Glycosides from Eugenia jambolana leaves. Phytochemistry 58: 1239 - 1244. 
Mudiana, D. 2007. Perkecambahan Syzigium cumini. Biodiversitas volume 8 no 1 cit MA Gafur, I. Isa dan N. Bialangi. Isolasi dan Identifikasi Senyawa Flavonoid dari Daun Jamblang (Syzigium cumini ).Makalah. Fakultas MIPA Universitas Negeri Gorontalo.

Mudita, I.W. 2012. Kapundung. http://tanamankampung.blogspot.co.i d/2012/03/kapundung.html . [5 Desember 2015]

Pinaria. A., A. Baihaki, R. Setimihardja, dan A.A. Daradjat. 1995. Variabilitas Genetik dan Heritabilitas KarakterKarakter Biomasa 53 Genotipe Kedelai. Zuriat, Vol. 6 (2): 88 - 92.
Soedomo, P. 2000. Evaluasi penampilan fenotipik dan hasil kacang kapri. J. Hort., Vol. 10 (3): 165 - 176.

Steel, R.G.D. dan J.H. Torrie. 1995. Prinsip dan Prosedur Statistika PT. Gramedia. Jakarta.

Suhardi, B. dan Rahmawati D. 2006. Potensi dan Wilayah Pengembangan Kesemek Junggo. Buletin Plasma Nutfah Vol.12 (2).

Swasti, E. 2007. Pengantar Pemuliaan Tanaman. Diktat. Fakultas Pertanian Universitas Andalas. Padang.

Tjitrosoepomo, G. 2009. Morfologi Tumbuhan. Gadjah Mada University Press. Jogjakarta. 